\title{
WILEY-VCH
}

Article type: Full Paper

\section{A novel high capacity positive electrode material with tunnel-type structure for aqueous sodium-ion batteries}

Yuesheng Wang, Linqin Mu, Jue Liu, Zhenzhong Yang, Xiqian Yu*, Lin Gu*, Yong-Sheng Hu*, Hong Li, Xiao-Qing Yang, Liquan Chen, Xuejie Huang

Mr. Y. Wang, Ms. L. Mu, Prof. Y. -S. Hu, Prof. H. Li, Prof. L. Chen, Prof. X. Huang Key Laboratory for Renewable Energy, Beijing Key Laboratory for New Energy Materials and Devices, Beijing National Laboratory for Condensed Matter Physics, Institute of Physics, Chinese Academy of Sciences, Beijing 100190, China.

E-mail: yshu@iphy.ac.cn

Mr. J. Liu, Dr. X. Yu, Dr. X. -Q. Yang

Brookhaven National Laboratory, Upton, NY11973, USA

E-mail: xyu@bnl.gov

Mr. Z. Yang, Prof. L. Gu.

Laboratory of Advanced Materials \& Electron Microscopy, Beijing National Laboratory for Condensed Matter Physics, Institute of Physics, Chinese Academy of Sciences, Beijing 100190, China.

E-mail: l.gu@iphy.ac.cn

Prof. L. Gu.

Collaborative Innovation Center of Quantum Matter, Beijing, China.

E-mail: l.gu@iphy.ac.cn

Keywords: Aqueous sodium ion battery, energy storage, positive electrode, tunnel-type structure

Abstract: Aqueous sodium-ion batteries have shown desired properties of high safety characteristics and low-cost for large-scale energy storage applications such as smart grid, because of the abundant sodium resources as well as the inherently safer aqueous electrolytes. Among various $\mathrm{Na}$ insertion electrode materials, tunnel-type $\mathrm{Na}_{0.44} \mathrm{MnO}_{2}$ has been widely investigated as a positive electrode for aqueous sodium-ion batteries. However, the low achievable capacity hinders its practical applications. Here we report a novel sodium rich tunnel-type positive material with a nominal composition of $\mathrm{Na}_{0.66}\left[\mathrm{Mn}_{0.66} \mathrm{Ti}_{0.34}\right] \mathrm{O}_{2}$. The 


\section{WILEY-VCH}

tunnel-type structure of $\mathrm{Na}_{0.44} \mathrm{MnO}_{2}$ obtained for this compound was confirmed by XRD and atomic-scale STEM/EELS. When cycled as positive electrode in full cells using $\mathrm{NaTi}_{2}\left(\mathrm{PO}_{4}\right)_{3} / \mathrm{C}$ as negative electrode in $1 \mathrm{M} \mathrm{Na}_{2} \mathrm{SO}_{4}$ aqueous electrolyte, this material shows the highest capacity of $76 \mathrm{mAh} \mathrm{g}^{-1}$ among the Na insertion oxides with an average operating voltage of $1.2 \mathrm{~V}$ at a current rate of $2 \mathrm{C}$. These results demonstrate that $\mathrm{Na}_{0.66}\left[\mathrm{Mn}_{0.66} \mathrm{Ti}_{0.34}\right] \mathrm{O}_{2}$ is a promising positive electrode material for rechargeable aqueous sodium-ion batteries.

\section{Introduction}

The concerns of global climate changing and environmental issues have inspired intensive research on energy storage technologies and their applications on electric vehicles and smart grid aiming the better utilization of renewable energy sources such as wind and solar. The rechargeable battery is one of the most important fields for large-scale electric energy storage $^{1,2}$. The most common rechargeable battery systems are lithium ion batteries (LIBs) with high energy density, high cycling efficiency and cycle stability. Although the LIBs have been successfully developed for portable electronics and electric vehicles, their applications for large-scale energy storage systems for smart grid still face significant challenges, due to cost, safety and cycle life issues ${ }^{3-5}$. As a result, sodium-ion batteries (SIBs) with similar intercalated electrochemistry to LIBs have been regarded as a promising alternative for such large scale applications due to the low cost and naturally abundant of the Na resources ${ }^{6-13}$. In particular, room temperature aqueous sodium-ion batteries have been focused on, because the aqueous electrolyte is inherently safer and more environmental friendly with potential to achieve higher power density than organic electrolytes ${ }^{14-30}$. Unlike in non-aqueous system the batteries can operate in a wide voltage range, the stable operating voltage window of the aqueous system is rather narrower. Suitable electrode materials for aqueous system should be operated in potential located between the $\mathrm{H}_{2}$ and $\mathrm{O}_{2}$ evolution potential ${ }^{31}$. In addition, the chemical stability of the electrode materials in $\mathrm{H}_{2} \mathrm{O}$ is another important aspect needs to be considered, which also restricts the suitable candidates as electrode materials for such batteries. Therefore, only few workable positive and negative electrode materials have been reported for aqueous SIBs, such as $\mathrm{Na}_{x} \mathrm{MnO}_{2}{ }^{32-42}$, Prussian blue analogues ${ }^{18-23}$ etc. For the positive electrode materials, $\mathrm{Na}_{0.44} \mathrm{MnO}_{2}$ with a tunnel structure is of particular interest and importance due to its unique structure with large channels, which is desirable for $\mathrm{Na}$ extraction/insertion, as well as its chemical and electrochemical stability in aqueous electrolytes ${ }^{34,38,39}$. The crystal structure of $\mathrm{Na}_{0.44} \mathrm{MnO}_{2}\left(\mathrm{Na}_{4} \mathrm{Mn}_{9} \mathrm{O}_{18}\right)$ is isostructural with $\mathrm{Na}_{4} \mathrm{Mn}_{4} \mathrm{Ti}_{5} \mathrm{O}_{18}$, which was first specified by Mumme ${ }^{43}$. This structure belongs to the space 


\section{WILEY-VCH}

group Pbam with orthorhombic symmetry ${ }^{36,44-46}$. The tunnel structure consists of double and triple rutile-type chains which are formed by edge-sharing $\mathrm{MnO}_{6}$ octahedra as well as single chains of corner-sharing $\mathrm{MnO}_{5}$. There are two types of tunnels in the structure: one is the small tunnel which is fully occupied by $\mathrm{Na}^{+}$ions, the other is the large S-shape tunnel which is half filled by $\mathrm{Na}^{+}$ions. Portion of the $\mathrm{Na}^{+}$ions located in S-shape tunnels can be reversibly extracted and reinserted, providing a capacity of $30 \sim 40 \mathrm{mAh} \mathrm{g}^{-1}$ in aqueous electrolytes as reported in the literature ${ }^{34,38,39}$. In fact, additional sodium ions can be reversibly inserted in the large S-tunnels by adjusting the redox reaction to fit with the operating voltage window of the aqueous system. Therefore, a higher capacity might be achievable if the tunnel structured framework can be further utilized.

Here, we report a stable Na-rich, Ti-substituted tunnel-type $\mathrm{Na}_{0.66}\left[\mathrm{Mn}_{0.66} \mathrm{Ti}_{0.34}\right] \mathrm{O}_{2}$ positive electrode material, synthesized through a simple solid state reaction method. To the best of our knowledge, this material demonstrates the highest reversible capacity of $76 \mathrm{mAh} \mathrm{g}^{-1}$ (2Crate) among the oxide electrode materials reported in aqueous SIBs with small polarization. It also exhibits excellent cyclic performance in full cells when coupled with the $\mathrm{NaTi}_{2}\left(\mathrm{PO}_{4}\right)_{3} / \mathrm{C}$ negative electrode, making it a quite promising positive electrode material for aqueous SIBs.

\section{Results}

2.1.Crystal structure of $\mathbf{N a}_{\mathbf{0 . 6}}\left[\mathbf{M n}_{\mathbf{0 . 6 6}} \mathbf{T i}_{\mathbf{0 . 3 4}}\right] \mathrm{O}_{2}$. If all sodium ions in the $\mathrm{Na}_{0.44} \mathrm{MnO}_{2}\left(\mathrm{Mn}^{3.56+}\right)$ electrode can be extracted, the theoretical capacity would be $122 \mathrm{mAh} \mathrm{g}^{-1}$, corresponding to sodium composition range of 0 to 0.44 . However, in practical cells, only half of these sodium can be cycled, because further sodium ion extraction would cause the damaging event of $\mathrm{O}_{2}$ evolution. On a simple consideration, if the valence state of the $\mathrm{Mn}$ in the as-synthesized tunnel-type material is lower than $\mathrm{Mn}^{3.56+}$ in $\mathrm{Na}_{0.44} \mathrm{MnO}_{2}\left(\mathrm{Mn}^{3.56+}\right)$, more sodium might be extracted and a higher capacity could be achieved, because the lower potential of the redox reaction of $\mathrm{Mn}$ ions can be utilized to prevent the $\mathrm{O}_{2}$ evolution. Our recent work indicates that in Ti-substituted $\mathrm{Na}_{0.44}\left[\mathrm{Mn}_{1-\mathrm{x}} \mathrm{Ti}_{\mathrm{x}}\right] \mathrm{O}_{2}(\mathrm{x}=0.11,0.22,0.33,0.39,0.44,0.56)$ samples the average valence state of $\mathrm{Mn}$ decreases with increasing $\mathrm{Ti}$ content. $\mathrm{Ti}$ atoms are inactive and remain at $\mathrm{Ti}^{4+}$ state $^{46}$. It is known that the lowest achievable valence state of $\mathrm{Mn}$ is $\mathrm{Mn}^{3+}$ for manganese oxides synthesized under high temperature calcination in air. By controlling the ratios of $\mathrm{Mn} / \mathrm{Ti}$ and $\mathrm{Na} /(\mathrm{Ti}+\mathrm{Mn})$ in $\mathrm{Na}_{\mathrm{x}}\left[\mathrm{Mn}_{\mathrm{x}} \mathrm{Ti}_{1-\mathrm{x}}\right] \mathrm{O}_{2}(0.44 \leqslant \mathrm{x}<0.66)$, the valence state of $\mathrm{Mn}$ could be obtained at $\mathrm{Mn}^{3+}$. A series of $\mathrm{Na}_{\mathrm{x}}\left[\mathrm{Mn}_{\mathrm{x}} \mathrm{Ti}_{1-\mathrm{x}}\right] \mathrm{O}_{2}(\mathrm{x}=0.44,0.50,0.55,0.60,0.63,0.66)$ samples was synthesized by solid state reaction method. Supplementary Fig. 1 shows the XRD patterns of $\mathrm{Na}_{\mathrm{x}}\left[\mathrm{Mn}_{\mathrm{x}} \mathrm{Ti}_{1-\mathrm{x}}\right] \mathrm{O}_{2}$, the phase purity was sensitive to the ratios of $\mathrm{Mn} / \mathrm{Ti}$ and 


\section{WILEY-VCH}

$\mathrm{Na} /(\mathrm{Ti}+\mathrm{Mn})$ in the reactants. When the $\mathrm{Mn} / \mathrm{Ti}$ ratio is too low or $\mathrm{Na} /(\mathrm{Ti}+\mathrm{Mn})$ ratio is too high, a small amount of impurities was observed. This indicates that at elevated temperatures during synthesis, there is a narrow optimized composition range for sodium to form the tunnel-type phase. The structure of tunnel phase with high sodium content has rarely been explored in the literature. Therefore, the crystal structure of the $\mathrm{Na}_{0.66}\left[\mathrm{Mn}_{0.66} \mathrm{Ti}_{0.34}\right] \mathrm{O}_{2}$ will be discussed in details in the following.

Synchrotron X-ray powder diffraction data of these samples was collected at X 14A beamline at NSLS by using rotational capillary mode with a wavelength of $0.7798 \AA$. The as-collected diffraction data can be best indexed by using space group Pbam with lattice parameters $a=9.21556(4), b=26.4903(8), c=2.87499(6)$. A further whole pattern Le Bail fitting was carried out to extract the corresponding (hkl) file for structure solution by using charge flipping algorithm in super flip. All atom positions were successfully identified, as can be seen in Fig. 1c. The obtained structure was used as initial model for further Rietveld refinement. The refined diffraction pattern is shown in Fig. 1a, and detailed structure information can be found in Supplementary Table 1, indicating that the as prepared $\mathrm{Na}_{0.66}\left[\mathrm{Mn}_{0.66} \mathrm{Ti}_{0.34}\right] \mathrm{O}_{2}$ is isostructural with a typical tunnel-type $\mathrm{Na}_{4}\left[\mathrm{Mn}_{4} \mathrm{Ti}_{5}\right] \mathrm{O}_{18}$ $\left(\mathrm{Na}_{0.44}\left[\mathrm{Mn}_{0.44} \mathrm{Ti}_{0.56}\right] \mathrm{O}_{2}\right)$. A small amount of impurity phase exists, however, its exact composition and structure cannot be identified and it is most likely to be $\mathrm{Na}_{\mathrm{x}} \mathrm{TiO}_{2}$ as proposed in previous research work ${ }^{40}$. The Na site occupancies in $\mathrm{Na}_{0.66}\left[\mathrm{Mn}_{0.66} \mathrm{Ti}_{0.34}\right] \mathrm{O}_{2}$ were precisely determined by the refinement. It is found that the $\mathrm{Na}$ at the $\mathrm{Na}(1)$ site is fully occupied, which is different from the observation in $\mathrm{Na}_{0.44}\left[\mathrm{Mn}_{0.66} \mathrm{Ti}_{0.34}\right] \mathrm{O}_{2}$ where the $\mathrm{Na} 1$ site is not fully occupied. The $\mathrm{Na}$ occupancies at the $\mathrm{Na}(2)$ and $\mathrm{Na}(3)$ sites are higher than the ideal occupancy of 0.5 in $\mathrm{Na}_{0.44}\left[\mathrm{Mn}_{0.44} \mathrm{Ti}_{0.56}\right] \mathrm{O}_{2}$ but not fully occupied, due to the short distance and strong repulsion between these sites, especially the short $\mathrm{Na}(3)-\mathrm{Na}(3)$ distance, as illustrated in Fig.1c. The total Na content calculated on the basis of the refinement is around 0.56, which is close to the designed composition during synthesis. Here we use the $\mathrm{Na}_{0.66}\left[\mathrm{Mn}_{0.66} \mathrm{Ti}_{0.34}\right] \mathrm{O}_{2}$ as a nominal composition. The Ti/Mn cation stoichiometry in each individual transition metal sites was also determined from the Rietveld refinement. It was revealed that $M n(1), M n(2)$, $\mathrm{Mn}(3)$ and $\mathrm{Mn}(4)$ sites were co-occupied by $\mathrm{Mn}^{3+} / \mathrm{Mn}^{4+}$ and $\mathrm{Ti}^{4+}$ in a disordered arrangement, while the $\mathrm{Mn}(5)$ site was solely occupied by $\mathrm{Mn}^{3+}$. Therefore, the material will not be expected to possess charge ordering as $\mathrm{Na}_{0.44} \mathrm{MnO}_{2}$ proposed in the early report ${ }^{36,45,46}$.

Advanced spherical aberration-corrected electron microscopy (STEM) experiments were carried out at atomic scale to further study the structure ${ }^{47}$. Fig. 2a shows the high-angle annular dark field (HAADF) image of the pristine $\mathrm{Na}_{0.66}\left[\mathrm{Mn}_{0.66} \mathrm{Ti}_{0.34}\right] \mathrm{O}_{2}$ recorded along the 


\section{WILEY-VCH}

[001] zone axis, with a clear indication of the typical tunnel structure. The large S-shaped tunnel and small hexagonal tunnel formed by $\mathrm{MnO}_{6}$ and $\mathrm{MnO}_{5}$ polyhedral can be clearly visualized. In addition, five different transition metal sites and three sodium sites are evidently distinguished in the image. To accurately confirm the Mn/Ti sites and their valence states, electron energy-loss spectrum (EELS) was performed. Fig. 2b, 2c display the corresponding EELS profiles of Mn-L2, L3 and Ti-L2, L3 edge for the pristine $\mathrm{Na}_{0.66}\left[\mathrm{Mn}_{0.66} \mathrm{Ti}_{0.34}\right] \mathrm{O}_{2}$ samples. It can be deduced that $\mathrm{Mn}$ and $\mathrm{Ti}$ are typically $\mathrm{Mn}^{3+}$ and $\mathrm{Ti}^{4+}$ states respectively. From the atomic-scale EELS shown in Fig. 2d, it can be found that $\mathrm{Mn}(1), \mathrm{Mn}(3), \mathrm{Mn}(4)$ are occupied by both Mn and Ti while Mn(2) site is mainly filled with Mn ions. At Mn(5) site, no signal from Ti can be seen. These results are in good agreement with the refinement of XRD pattern.

2.2.Sodium storage performance. The sodium storage performances of $\mathrm{Na}_{0.66}\left[\mathrm{Mn}_{0.66} \mathrm{Ti}_{0.34}\right] \mathrm{O}_{2}$ were tested first in non-aqueous electrolyte media using $\mathrm{Na}_{0.66}\left[\mathrm{Mn}_{0.66} \mathrm{Ti}_{0.34}\right] \mathrm{O}_{2} \mid \mathrm{Na}$ half cells cycled in the voltage range of 2.5-3.9 V under a current rate of $0.1 \mathrm{C}\left(11.8 \mathrm{~mA} \mathrm{~g}^{-1}\right)$. The typical charge-discharge curves shown in Fig. 3a exhibit a sloping voltage profile, significantly different from that of the un-substituted $\mathrm{Na}_{0.44} \mathrm{MnO}_{2}$ where multiple plateaus are usually observed. The $\mathrm{Mn}^{3+} / \mathrm{Mn}^{4+}$ charge ordering existed in $\mathrm{Na}_{0.44} \mathrm{MnO}_{2}$ has been destroyed due to the disordered $\mathrm{Mn} / \mathrm{Ti}$ arrangement in $\mathrm{Na}_{0.66}\left[\mathrm{Mn}_{0.66} \mathrm{Ti}_{0.34}\right] \mathrm{O}_{2}$, which is in consistent with the Rietveld refinement results. The halfcell delivers a reversible capacity of ca. $74 \mathrm{mAh} \mathrm{g}^{-1}$ (corresponding to $0.28 \mathrm{Na}$ insertion per formula unit), much higher than that of the $\mathrm{Na}_{0.44}\left[\mathrm{Mn}_{0.44} \mathrm{Ti}_{0.56}\right] \mathrm{O}_{2} \mid \mathrm{Na}$ half-cell at the same cutoff voltage (ca. $\left.50 \mathrm{mAh} \mathrm{g}^{-1}\right)^{46}$. This proves that additional $\mathrm{Na}^{+}$ions were successfully incorporated into $\mathrm{Na}_{0.66}\left[\mathrm{Mn}_{0.66} \mathrm{Ti}_{0.34}\right] \mathrm{O}_{2}$ and can also be reversibly inserted into the tunnel structure. The average Na storage potential is found to be around $3.2 \mathrm{~V}$ vs. $\mathrm{Na}^{+} / \mathrm{Na}$, located between that of $\mathrm{O}_{2}$ and $\mathrm{H}_{2}$ evolution (2.297 and $3.527 \mathrm{~V}$ vs. $\mathrm{Na}^{+} / \mathrm{Na}$ at neutral $\mathrm{pH}$ ) to avoid water oxidation during electrochemical cycling. Therefore, this material is suitable to be used as the positive electrode application in aqueous electrolyte system.

An aqueous sodium-ion full cell was constructed using $\mathrm{Na}_{0.66}\left[\mathrm{Mn}_{0.66} \mathrm{Ti}_{0.34}\right] \mathrm{O}_{2}$ as the positive electrode and $\mathrm{NaTi}_{2}\left(\mathrm{PO}_{4}\right)_{3} / \mathrm{C}$ as the negative electrode. The full cell charged and discharged between 0.3-1.7 V delivers a much higher reversible capacity of $c a .76 \mathrm{mAh} \mathrm{g}^{-1}$ at current rate of $2 \mathrm{C}$, which is the highest among all materials reported for positive electrodes in aqueous sodium-ion batteries to date. It also gives an average operating voltage of $1.2 \mathrm{~V}$, which is comparable to that of the Prussian blue analogues ${ }^{18-23}$. The Na storage performance of the reference material $\mathrm{Na}_{0.44}\left[\mathrm{Mn}_{0.44} \mathrm{Ti}_{0.56}\right] \mathrm{O}_{2}$ in aqueous electrolyte was also tested and the results 


\section{WILEY-VCH}

are shown in Fig. 4 in comparison with $\mathrm{Na}_{0.66}\left[\mathrm{Mn}_{0.66} \mathrm{Ti}_{0.34}\right] \mathrm{O}_{2}$. A reversible capacity of 45 mAh g ${ }^{-1}$ was obtained for $\mathrm{Na}_{0.44}\left[\mathrm{Mn}_{0.44} \mathrm{Ti}_{0.56}\right] \mathrm{O}_{2}$ electrode, which is much lower than that of $\mathrm{Na}_{0.66}\left[\mathrm{Mn}_{0.66} \mathrm{Ti}_{0.34}\right] \mathrm{O}_{2}$ electrode, when cycling under the same current rate of $2 \mathrm{C}$ in a voltage range of $0.3-1.7 \mathrm{~V}$. This result is in good agreement with non-aqueous sodium-ion battery test. The rate capability of the $\mathrm{Na}_{0.66}\left[\mathrm{Mn}_{0.66} \mathrm{Ti}_{0.34}\right] \mathrm{O}_{2}$ electrode was also evaluated in full cells and the results are shown in Fig. 4c. The $\mathrm{Na}_{0.66}\left[\mathrm{Mn}_{0.66} \mathrm{Ti}_{0.34}\right] \mathrm{O}_{2} \mid \mathrm{NaTi}_{2}\left(\mathrm{PO}_{4}\right)_{3} / \mathrm{C}$ full cell exhibits excellent rate performance. A specific capacity of approximately $54 \mathrm{mAh} \mathrm{g}^{-1}$ was achieved at a high rate of 10C (6 min charging/discharging), which is about $71 \%$ of the capacity at $2 \mathrm{C}$ rate. It is worthwhile to note that the $\mathrm{Na}_{0.66}\left[\mathrm{Mn}_{0.66} \mathrm{Ti}_{0.34}\right] \mathrm{O}_{2}$ sample particles used in this study are mainly in micron size, further optimization of rate performance could be possible if particle size is further optimized. For aqueous sodium-ion batteries, the capacity fading at low rates observed in most of aqueous full cell systems is caused by either partial dissolution of electrode materials, or oxidation of the anode in its sodium-inserted state by dissolved oxygen or oxygen generated from overcharged cathode. It is interesting to find that the $\mathrm{Na}_{0.66}\left[\mathrm{Mn}_{0.66} \mathrm{Ti}_{0.34}\right] \mathrm{O}_{2}$ demonstrates excellent long-term cycling stability under relative low rate. As shown in Fig. 4 d, the $\mathrm{Na}_{0.66}\left[\mathrm{Mn}_{0.66} \mathrm{Ti}_{0.34}\right] \mathrm{O}_{2} \mid \mathrm{NaTi}_{2}\left(\mathrm{PO}_{4}\right)_{3} / \mathrm{C}$ full cell exhibits a stable cycling behavior over 300 cycles with capacity retention of $89 \%$ at a current rate of 2C. The Coulombic efficiency after initial cycles can reach nearly 99\%. As far as we know, tunneltype $\mathrm{Na}_{0.66}\left[\mathrm{Mn}_{0.66} \mathrm{Ti}_{0.34}\right] \mathrm{O}_{2}$ exhibits the highest gravimetric capacity and excellent cyclic stability among the sodium containing oxide positive electrode materials for aqueous sodiumion batteries.

\section{Discussion}

Manganese-oxygen-sodium ternary system (for $\mathrm{Na} / \mathrm{Mn}<1$ ) has been well studied in Parant's previous work, whereas the tunnel $\mathrm{Na}_{0.44} \mathrm{MnO}_{2}$ was first identified in the $\mathrm{Na}_{\mathrm{x}} \mathrm{MnO}_{2}$ phase diagram and found to be thermodynamically stable under high temperature for $\mathrm{x}<0.5^{32,33,48,49}$. A higher sodium occupancy of $\mathrm{x}>0.5$ in tunnel $\mathrm{Na}_{\mathrm{x}} \mathrm{MnO}_{2}$ is energetically unfavorable due to the repulsion of the sodium ions within the S-shape tunnels ${ }^{36}$. However, it is interesting to note that the Ti-substituted $\mathrm{Na}_{0.66}\left[\mathrm{Mn}_{0.66} \mathrm{Ti}_{0.34}\right] \mathrm{O}_{2}$ can stabilize the tunnel structure while allowing a higher sodium content than that in $\mathrm{Na}_{\mathrm{x}} \mathrm{MnO}_{2}$. The formula of the $\mathrm{Na}_{0.66}\left[\mathrm{Mn}_{0.66} \mathrm{Ti}_{0.34}\right] \mathrm{O}_{2}$ can be written as $\mathrm{Na}_{0.66}\left[\mathrm{Mn}^{3+}{ }_{0.66} \mathrm{Ti}^{4+}{ }_{0.34}\right] \mathrm{O}_{2}$, where all the $\mathrm{Mn}$ ions are in $\mathrm{Mn}^{3+}$ state. This is quite different from that in un-substituted $\mathrm{Na}_{0.44} \mathrm{MnO}_{2}$ $\left(\mathrm{Na}_{0.44} \mathrm{Mn}_{0.44}{ }^{3+} \mathrm{Mn}_{0.56}{ }^{4+} \mathrm{O}_{2}\right)$. It is known that $\mathrm{Mn}^{3+}$ possesses two particular features: (1) It has four unpaired electrons with parallel spin, giving the ion a large magnetic moment; and (2) It 


\section{WILEY-VCH}

exhibits large Jahn-Teller distortion due to the single occupancy of a degenerate $\mathrm{e}_{\mathrm{g}}$ orbital. Both are important factors in deciding the energy difference between different structures ${ }^{50}$. This is well demonstrated in $\mathrm{LiMnO}_{2}\left(\mathrm{Mn}^{3+}\right)$ that the structure stabilizes the orthorhombic phase rather than monoclinic layered phase, and low valence doping ( such as $\mathrm{Zn}^{2+}$ or $\mathrm{Ni}^{2+}$ ) introduces $\mathrm{Mn}^{4+}$ ions that perturb the magnetic arrangement thus enhancing the monoclinic layered structure ${ }^{51}$. This may also be the reason that why $\mathrm{Na}_{0.66}\left[\mathrm{Mn}_{0.66} \mathrm{Ti}_{0.34}\right] \mathrm{O}_{2}$ can be stabilized in orthorhombic tunnel structure.

Another interesting aspect is that the $\mathrm{Mn}^{3+} / \mathrm{Mn}^{4+}$ charge ordering observed in $\mathrm{Na}_{0.44} \mathrm{MnO}_{2}$ is destroyed because of the very similar ionic ratio between $\mathrm{Mn}^{3+}$ and $\mathrm{Ti}^{4+}$ and substantially large difference in redox potential between $\mathrm{Mn}^{3+} / \mathrm{Mn}^{4+}$ and $\mathrm{Ti}^{3+} / \mathrm{Ti}^{4+}$ as discussed in our recent work ${ }^{52}$, leading to a random arrangement of $\mathrm{Mn}^{3+}$ and $\mathrm{Ti}^{4+}$ on all octahedral sites in $\mathrm{Na}_{0.66}\left[\mathrm{Mn}_{0.66} \mathrm{Ti}_{0.34}\right] \mathrm{O}_{2}$. Therefore, the $\mathrm{Na}_{0.66}\left[\mathrm{Mn}_{0.66} \mathrm{Ti}_{0.34}\right] \mathrm{O}_{2}$ half-cell exhibits a sloping voltage profile, unlike the $\mathrm{Na}_{0.44} \mathrm{MnO}_{2}$ where multiple plateaus were observed during $\mathrm{Na}$ extraction/insertion related to a series of phase transitions (charge ordering and/or $\mathrm{Na}^{+} /$vacancy ordering). To further understand the structural changes in $\mathrm{Na}_{0.66}\left[\mathrm{Mn}_{0.66} \mathrm{Ti}_{0.34}\right] \mathrm{O}_{2}$ during $\mathrm{Na}$ extraction and insertion, in situ XRD experiment was performed on a $\mathrm{Na}_{0.66}\left[\mathrm{Mn}_{0.66} \mathrm{Ti}_{0.34}\right] \mathrm{O}_{2} \mid \mathrm{Na}$ half-cell in a wide voltage range of $1.5-3.9 \mathrm{~V}$ (vs. $\mathrm{Na}^{+} / \mathrm{Na}$ ) and the results are presented in Fig. 5. Most of the XRD reflections (e.g.,(040), (210), (140), (201)) display continuous peak shift during Na extraction/insertion. There is no evident appearance of a new phase formation upon $\mathrm{Na}$ extraction/insertion from/into $\mathrm{Na}_{0.66}\left[\mathrm{Mn}_{0.66} \mathrm{Ti}_{0.34}\right] \mathrm{O}_{2}$ in a wide $\mathrm{Na}$ content range. The main tunnel structure of the $\mathrm{Na}_{0.66}\left[\mathrm{Mn}_{0.66} \mathrm{Ti}_{0.34}\right] \mathrm{O}_{2}$ was maintained during the entire charge/discharge process without obvious structure transformation. This is similar to the phase transition behavior revealed in our recent work on $\mathrm{Na}_{0.44}\left[\mathrm{Mn}_{0.44} \mathrm{Ti}_{0.56}\right] \mathrm{O}_{2}{ }^{46}$. In particular, the phase evolution exhibits a symmetric behavior between the charge and discharge processes in the voltage range of 2.7-3.9 V, showing that the phase evolution proceeds through a solid solution reaction upon the initial charge process until $3.9 \mathrm{~V}$ and reversibly through the almost identical solid solution pathway to the pristine structure upon discharge to $2.7 \mathrm{~V}$. It indicates a high structure stability of $\mathrm{Na}_{0.66}\left[\mathrm{Mn}_{0.66} \mathrm{Ti}_{0.34}\right] \mathrm{O}_{2}$ during $\mathrm{Na}$ extraction and insertion, which can explain the excellent cycle performance in both nonaqueous and aqueous electrolyte. Furthermore, the solid solution phase transition behavior ${ }^{53}$, which is induced by Ti-substitution, is also expected to enhance the high-rate capability and cycling stability of the $\mathrm{Na}_{0.66}\left[\mathrm{Mn}_{0.66} \mathrm{Ti}_{0.34}\right] \mathrm{O}_{2}$ material.

\section{Conclusion}




\section{WILEY-VCH}

In summary, $\mathrm{Na}_{0.66}\left[\mathrm{Mn}_{0.66} \mathrm{Ti}_{0.34}\right] \mathrm{O}_{2}$ was successfully designed and synthesized by a simple solid-state method and its structure was systematically studied using synchrotron powder XRD, atomic-scale STEM and EELS. It retains the orthorhombic structure (space group: Pbam), which is similar to the structure of tunnel-type $\mathrm{Na}_{0.44} \mathrm{MnO}_{2}$ and distinguished from P2- $\mathrm{Na}_{0.66} \mathrm{MnO}_{2}$ with layered structure (space group: P63/mmc). It has been found that $\mathrm{Na}_{0.66}\left[\mathrm{Mn}_{0.66} \mathrm{Ti}_{0.34}\right] \mathrm{O}_{2}$ can be used as a positive electrode material for aqueous sodium-ion batteries. In particular, it shows the highest reversible capacity of ca. $76 \mathrm{mAh} \mathrm{g}^{-1}$ at a current rate of $2 \mathrm{C}$ among all the oxide electrode materials, with an average operating voltage of $1.2 \mathrm{~V}$ when coupled with $\mathrm{NaTi}_{2}\left(\mathrm{PO}_{4}\right)_{3} / \mathrm{C}$ negative electrode in aqueous sodium-ion batteries. Another appealing feature is that the material retains tunnel structure without phase transformation during $\mathrm{Na}$ extraction and insertion, which ensures the prolonged cycle stability. The $\mathrm{Na}_{0.66}\left[\mathrm{Mn}_{0.66} \mathrm{Ti}_{0.34}\right] \mathrm{O}_{2} \mid \mathrm{NaTi}_{2}\left(\mathrm{PO}_{4}\right)_{3} / \mathrm{C}$ aqueous sodium ion full cell demonstrates excellent cycle performance with very small capacity decay after 300 cycles. We believe that $\mathrm{Na}_{0.66}\left[\mathrm{Mn}_{0.66} \mathrm{Ti}_{0.34}\right] \mathrm{O}_{2}$ with outstanding performance represents a novel and attractive positive electrode material that would open a new approach for the development of low cost and nontoxic aqueous sodium-ion batteries for large-scale electrical energy storage systems.

\section{Experimental section:}

Material synthesis: The resulting material was prepared by a solid state reaction using precursors of $\mathrm{Na}_{2} \mathrm{CO}_{3}$ (99\%), $\mathrm{Mn}_{2} \mathrm{O}_{3}$ and $\mathrm{TiO}_{2}$ (99.5\%). An excess of $2 \mathrm{~mol} \% \mathrm{Na}_{2} \mathrm{CO}_{3}$ was used to compensate the Na loss during high temperature synthesis. The starting materials were ground in an agate mortar and pressed into pellets under pressure of $20 \mathrm{MPa}$. Then the pellets were heated at $900{ }^{\circ} \mathrm{C}$ for $12 \mathrm{~h}$ in an alumina crucible. $\mathrm{NaTi}_{2}\left(\mathrm{PO}_{4}\right)_{3}$ sample was prepared by a sol-gel method. Stoichiometric amounts of $\mathrm{NaNO}_{3}, \mathrm{NH}_{4} \mathrm{H}_{2} \mathrm{PO}_{4}$ and citric acid were dissolved in deionized (DI) water. Then, a diluted solution of tetrabutoxytitanium in ethanol was poured into the solution to reach the final stoichiometry under vigorously stirring. After the solvent evaporation, the gel precursor was annealed at $700{ }^{\circ} \mathrm{C}$ for $12 \mathrm{~h}$ under an air atmosphere. The carbon-coated $\mathrm{NaTi}_{2}\left(\mathrm{PO}_{4}\right)_{3}$ sample was prepared by a chemical vapour deposition (CVD) method. The $\mathrm{NaTi}_{2}\left(\mathrm{PO}_{4}\right)_{3}$ powders were put into a quartz tube furnace and a toluene $\left(\mathrm{C}_{7} \mathrm{H}_{8}\right)$ vapour was carried by Ar gas. The pyrolysis temperature for toluene was kept at $800{ }^{\circ} \mathrm{C}$ for 6 h, respectively. The carbon content in the $\mathrm{NaTi}_{2}\left(\mathrm{PO}_{4}\right)_{3} / \mathrm{C}$ composite was about $6 \%$ by mass.

Characterizations: In situ and ex situ XRD experiments were performed at beamline X14A with a $1 \mathrm{D}$ linear position sensitive detector at a distance of about $1.4 \mathrm{~m}$ to the sample center 


\section{WILEY-VCH}

and a wavelength of approximately $0.78 \AA$. Detailed in situ experimental configurations are reported in our previous paper ${ }^{54}$. Structure of $\mathrm{Na}_{0.66}\left[\mathrm{Mn}_{1-\mathrm{x}} \mathrm{Ti}_{\mathrm{x}}\right] \mathrm{O}_{2}$ was directly solved from synchrotron powder XRD data by using charge flipping method in Jana 2006 (superflip implemented). All atoms including $\mathrm{O}$ were successfully identified. This compound was found to have essential similar crystal structure as $\mathrm{Na}_{0.44}\left[\mathrm{Mn}_{1-\mathrm{x}} \mathrm{Ti}_{\mathrm{x}}\right] \mathrm{O}_{2}$ compounds, however, almost no anisotropic peak broadening was found for this sample. Further Rietveld refinement was carried out in TOPAS 4.2 with similar procedure mentioned in the previous paragraph. During refinement, atomic displacement of $\mathrm{Na}, \mathrm{Mn}$ and $\mathrm{Ti}$ was fixed, while all other parameters including atomic positions and site occupancies were refined simultaneously until the refinement converged. A JEM-ARM200F STEM fitted with a double aberration-corrector for both probe-forming and imaging lenses is used to perform HAADF imaging, which was operated at $200 \mathrm{kV}$. The convergence angle was $25 \mathrm{mrad}$ and the angular range of collected electrons for HAADF imaging is about $70-250 \mathrm{mrad}$.

Electrochemistry: For test in non-aqueous electrolyte, the working electrode was prepared by spreading the slurry of the active materials (75 wt. \%), acetylene black (15 wt. \%) and the polyvinylidene fluoride (PVDF) (10 wt.\%) binder on Al foil. The working electrodes were dried at $100{ }^{\circ} \mathrm{C}$ under vacuum for $10 \mathrm{~h}$. The electrolyte is $1 \mathrm{M} \mathrm{NaClO}_{4}$ in EC: DEC (4:6 in volume). The coin-type (CR2032) cells were assembled with pure sodium foil as the counter electrode, and a glass fiber as the separator in an argon-filled glove box. For test in aqueous electrolyte, the positive and negative electrodes were fabricated by mixing $75 \mathrm{wt}$. \% active materials with 20wt. \% acetylene black and 5wt. \% polytetrafluoroethylene (PTFE, Aldrich). The mixtures were pressed into titanium mesh. The electrolyte is $1 \mathrm{M} \mathrm{Na}_{2} \mathrm{SO}_{4}$ (Alfa) in DI water ( $\mathrm{pH}=7$ ) purged with $\mathrm{N}_{2}$ flow for $1 \mathrm{~h}$ before use in order to remove the dissolved $\mathrm{O}_{2}$. The full cells (CR2032) were assembled with $\mathrm{Na}_{0.66}\left[\mathrm{Mn}_{0.66} \mathrm{Ti}_{0.34}\right] \mathrm{O}_{2}$ positive electrode and $\mathrm{NaTi}_{2}\left(\mathrm{PO}_{4}\right)_{3} / \mathrm{C}$ negative electrode in a nitrogen-filled glove box $\left(\mathrm{O}_{2}\right.$ content is below 10 ppm).The weight ratio of cathode and anode was 1.45:1. The loadings for the positive and negative electrodes are $3.915 \mathrm{mg}$ and $2.45 \mathrm{mg}$, respectively. The charge and discharge measurements for both non-aqueous and aqueous batteries were carried out on a Land BT2000 battery test system (Wuhan, China) in a voltage range of 2.5-3.9 V and 0.3-1.7 V under room temperature.

\section{Acknowledgement:}




\section{WILEY-VCH}

This work was supported by funding from the NSFC (51222210, 11234013), “973” Projects (2012CB932900), and the One Hundred Talent Project of the Chinese Academy of Sciences. The work at Brookhaven National Laboratory was supported by the U.S. Department of Energy, the Assistant Secretary for Energy Efficiency and Renewable Energy, Office of Vehicle Technologies under Contract Number DE-SC0012704. The authors acknowledge beamline X14A at NSLS (BNL) and beamline 11-BM-B, 9-BM-B at APS (ANL).

\section{Additional information:}

Supporting Information is available from the Wiley Online Library or from the author.

\section{Competing financial interests:}

The authors declare no competing financial interests.

\section{References}

[1] B. Dunn, H. Kamath, J. M. Tarascon. Science 2011, 334, 928-935.

[2] Z. G. Yang, J. L. Zhang, C. W. Michael, K.-Meyer, X. C. Lu, C. Daiwon, J. P. Lemmon, J. Liu. Chem. Rev. 2011, 111, 3577-3613.

[3] M. Armand, J. M. Tarascon. Nature 2008, 451, 652-657.

[4] C. X. Zu, H. Li. Energy Environ. Sci. 2011, 4, 2614-2624 .

[5] L. M. Suo, Y. S. Hu, H. Li, M. Armand, L. Q. Chen. Nat. Commun. 2013, 4, 2513.

[6] C. Delmas, J. -J. Braconnier, C. Fouassier, P. Hagenmuller. Solid State Ionics 1981, 3-4, 165-169.

[7] S. Okada, Y. Takahashi, T. Kiyabu, T. Doi, J. -I. Yamaki, T Nishida. Meeting Abstracts 2006, MA2006-02, 201.

[8] S. Komaba, W. Murata, T. Ishikawa, N. Yabuuchi, T. Ozeki, T. Nakayama, A. Ogata, K. Gotoh, and K. Fujiwara. Adv. Funct. Mater. 2011, 21, 3859-3867.

[9] S. W. Kim, D. H. Seo, X. H. Ma, G. Ceder, K. Kang. Adv. Energy Mater. 2012, 2, 710721.

[10] H. L. Pan, Y. S. Hu, L. Q. Chen. Energy Environ. Sci. 2013, 6, 2338-2360.

[11] V. Palomares, M. Casas-Cabanas, E. Castillo-Martinez, M. H. Han, T. Rojo. Energy Environ. Sci. 2013, 6, 2312-2337.

[12] M. D. Slater, D. Kim, E. Lee, C. S. Johnson. Adv. Funct. Mater. 2013, 23, 947-958. 


\section{WILEY-VCH}

[13] N. Yabuuchi, K. Kubota, M. Dahbi, S. Komaba. Chem. Rev. 2014, 114, 11636-11682.

[14] H. Kim, J. Hong, K. -Y. Park, H. Kim, S. -W. Kim, K. Kang. Chem. Rev. 2014, 114, 11788-11827.

[15] Y. G. Wang, J. Yi, Y. Y. Xia. Adv. Energy Mater. 2012, 2, 830-840 .

[16] W. Li, J. R. Dahn, D. S. Wainwright. Science 1994, 264, 1115-1118.

[17] S. I. Park, I. Gocheva, S. Okada, J. J. Yamaki. Electrochem. Soc. 2011, 158, A1067A1070.

[18] C. D. Wessells, S. V. Peddada, R. A. Huggins, Y. Cui. Nano Lett. 2011, 11, 5421-5425.

[19] C. D. Wessells, R. A. Huggins, Y. Cui. Nat. Commun. 2011, 2, 550.

[20] M. Pasta, C. D. Wessells, R. A. Huggins, Y. Cui. Nat. Commun. 2012, 3, 1149.

[21] M. Pasta, CD. Wessells, N. Liu, J. Nelson, M. T. McDowell, R. A. Huggins, M. F. Toney, Y. Cui. Nat. Commun. 2014, 5, 4407

[22] X. Y. Wu, Y. L. Cao, X. P. Ai, J. F. Qian, H. X. Yang. Electrochem. Commun. 2013, 31, 145-148.

[23] X. Y. Wu, M. Y. Sun, Y. -F. Shen, J. -F. Qian, Y. L. Cao, X. P. Ai, H. X. Yang. ChemSusChem 2014, 7, 407-411.

[24] Y. Liu, Y. Qiao, W. X. Zhang, H. H. Xu, Z. Li, Y. Shen, L. X. Yuan, X. L. Hu, X. Dai, Y. H. Huang. Nano Energy 2014, 5, 97-104.

[25] H. Qin, Z. P. Song, H. Zhan, Y. H. Zhou. J. Power Sources 2014, 249, 367-372.

[26] Z. Hou, X. Li, J. Liang, Y. Zhu, Y. Qian. J. Mater. Chem. A 2015, 3, 1400-1404.

[27] B. H. Zhang, Y. Liu, X. W. Wu, Y. Q. Yang, Z. Chang, Z. B. Wen and Y. P. Wu. Chem. Commun. 2014, 50, 1209-1211.

[28] Y. H. Jung, C. H. Lim, J. H. Kim, D. K. Kim. Rsc Adv. 2014, 4, 9799-9802.

[29] W. X. Song, X. B. Ji, Y. R. Zhu, H. J. Zhu, F. Q. Li, J. Chen, F. Lu, Y. P. Yao and Craig. E. Banks. ChemElectroChem 2014, 1, 871-876.

[30] P. R. Kumar, Y. H. Jung, C. H. Lim, D. K. Kim. J. Mater. Chem. A 2015, 3, 6271-6275.

[31] J. -Y. Luo, W. -J. Cui, P. He, Y. -Y. Xia. Nat. Chem. 2010, 2, 760-765.

[32] M. M. Doeff, M. Y. Peng, Y. P. Ma \& L. C Dejonghe. J. Electrochem. Soc. 1994, 141, L145-L147.

[33] M. M. Doeff, T. J. Richardson, L. Kepley. J. Electrochem. Soc. 1996, 143, 2507-2516.

[34] J. F. Whitacre, A. Tevar, S. Sharma. Electrochem. Commun. 2010, 12, 463-466.

[35] Y. L. Cao, L. F. Xiao, W. Wang, D. Choi, Z. M. Nie, J. G. Yu, L. V. Saraf, Z. G. Yang, J. Liu. Adv. Mater. 2011, 23, 3155. 


\section{WILEY-VCH}

[36] H. J. Kim, D. J. Kim, D. -H. Seo, M. S. Yeom, K. Kang, D. K. Kim, and Y. S. Jung. Chem. Mater. 2012, 24, 1205-1211.

[37] E. Hosono, T. Saito, J. Hoshino, M. Okubo, Y. Saito, D. Nishio-Hamane, T. Kudo, H. S. Zhou. J. Power Sources 2012, 217, 43-46.

[38] Z. Li, D. Young, K. Xiang, W. C. Carter, Y. -M. Chiang. Adv. Energy Mater. 2013, 3, 290-294.

[39] D. J. Kim, R. Ponraj, A. G. Kannan, H. -W. Lee, R. Fathi, R. Ruffo, C. M. Mari, D. K. Kim. J. Power Sources 2013, 244, 758-763.

[40] M. M. Doeff, T. J. Richardson, K. -T. Hwang. J. Power Sources 2004, 135, 240-248.

[41] F. Funabiki, H. Hayakawa, N. Kijima, J. Akimoto. Electrochem. Solid-State Lett. 2009, 12, F35.

[42] F. Sauvage, L. Laffont, J. M. Tarascon. \& E. Baudrin. Inorg. Chem. 2007, 46,3289-3294.

[43] W. G. Mumme. Acta Crystallographica Section B-Structural Crystallography and Crystal Chemistry B 1968, 24, 1114.

[44] J. Akimoto, H. Hayakawa, N. Kijima, J. Awaka, F. Funabiki. Solid State Phen. 2011, 170, 198-202.

[45] I. Kruk, P. Zajdel, W. V. Beek, I. Bakaimi , A. Lappas, C. Stock, and A. M. Green. J. Am. Chem. Soc. 2011, 133, 13950-13956.

[46] Y. S. Wang, J. Liu, B. Lee, R. M. Qiao, Z. Z. Yang, S.-Y Xu, X. Q. Yu, L. Gu, Y-S Hu, W. L. Yang, K. Kang, H. Li, X. -Q. Yang, L. Q. Chen \& X. J. Huang. Nat. Commun. 2015, 6, 6401.

[47] R. Huang, Y. Ikuhara. Curr. Opin. Solid State Mater. Sci. 2012, 16, 31-38.

[48] J. -P. Parant, R. Olazcuaga, M. Devalette, C. Fouassier, P. Hagenmuller. J. Solid State Chem. 1971, 3, 1-11.

[49] A. Mendiboure, C. Delmas, P Hagenmuller. J. Solid State Chem. 1985, 57, 323-331.

[50] X. Li, X. H. Ma, D. Su, L. Liu, R. Chisnell, S. P. Ong, H. L. Chen, A. Toumar, J. -C. Idrobo, Y. C. Lei, J. M. Bai, F. Wang, J. W. Lynn, Y. S. Lee, G. Ceder. Nat. Mater. 2014, 13, 586-592.

[51] G. Ceder, S. K. Mishra. Electrochem. Solid State Lett. 1999, 2, 550-552.

[52] Y. S. Wang, R. j. Xiao, Y. -S. Hu, M. Avdeev, L. Q. Chen. Nat. Commun. 2015, 6, 6954.

[53] H. Liu, F. C. Strobridge, O. J. Borkiewicz, K. M. Wiaderek, K. W. Chapman, P. J. Chupas, C. P. Grey. Science 2014, 344, 6191.

[54] X. Q. Yu, Y. C. Lyu, L. Gu, H. M. Wu, S. M. Bak, Y. N. Zhou, K. Amine, S. N .Ehrlich, H. Li, K. -W. Nam, and X. -Q. Yang. Adv. Energy Mater. 2014, 4, 1300950. 


\section{WILEY-VCH}

Figures and Tables:

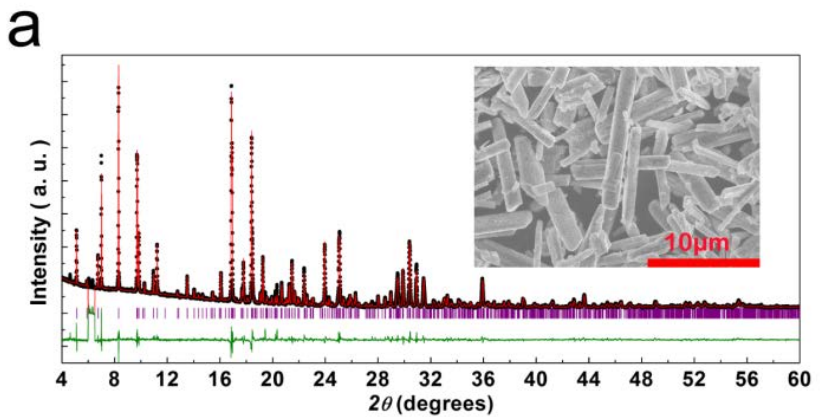

b

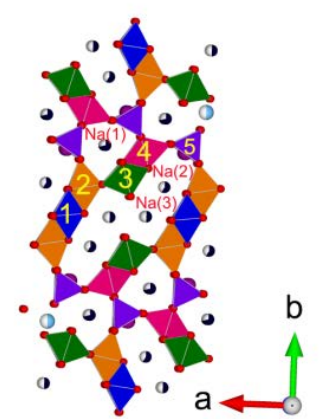

C

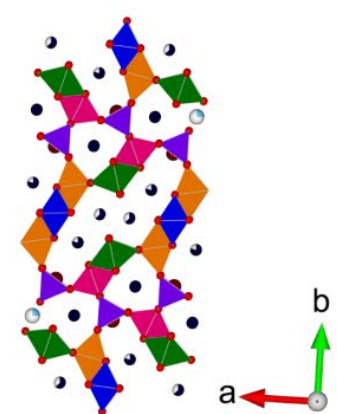

Figure 1 | Structure of $\mathbf{N a}_{0.66}\left[\mathbf{M n}_{\mathbf{0 . 6 6}} \mathbf{T i}_{\mathbf{0 . 3 4}}\right] \mathbf{O}_{2}$. (a) The Rietveld plot $(\lambda=0.7785 \AA)$ for refined $\mathrm{Na}_{0.66}\left[\mathrm{Mn}_{0.66} \mathrm{Ti}_{0.34}\right] \mathrm{O}_{2}$ synchrotron XRD pattern with experimental data in black dots, calculated curve in red and difference curve in olive. The inset shows the typical SEM image of the as-synthesized sample. A rod-like structure was revealed with average diameter of 0.5 $\mu \mathrm{m}$ and length of $6 \mu \mathrm{m}$. Scale bar: $10 \mu \mathrm{m}$. (b) $\mathrm{Na}_{0.44}\left[\mathrm{Mn}_{0.66} \mathrm{Ti}_{0.34}\right] \mathrm{O}_{2}$ and (c) $\mathrm{Na}_{0.66}\left[\mathrm{Mn}_{0.66} \mathrm{Ti}_{0.34}\right] \mathrm{O}_{2}$, sodium occupancy can be visualized by the filled in of the dark color on each individual sodium sites.

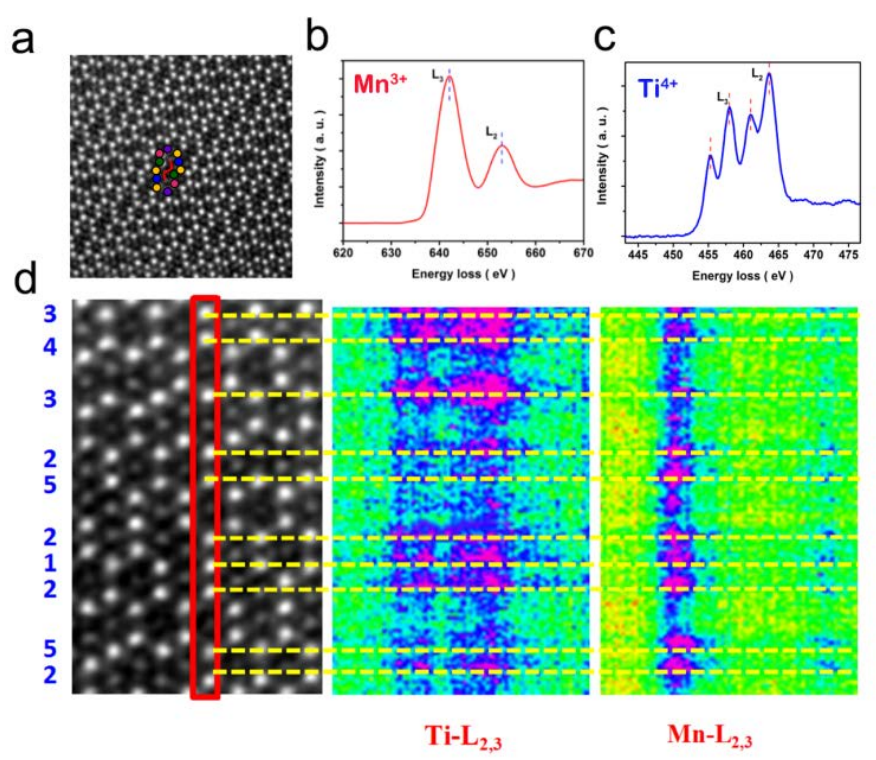

Figure 2 | STEM imaging. (a) General view of the crystal structure and view along [001] zone axis. Electron energy-loss spectra (EELS) for (b) $M n-L_{2,3}$ and (c) Ti- $\mathrm{L}_{2,3}$ edges for the pristine $\mathrm{Na}_{0.66}\left[\mathrm{Mn}_{0.66} \mathrm{Ti}_{0.34}\right] \mathrm{O}_{2}$ (d) The STEM-EELS image of $\mathrm{Na}_{0.66}\left[\mathrm{Mn}_{0.66} \mathrm{Ti}_{0.34}\right] \mathrm{O}_{2}$. 
a

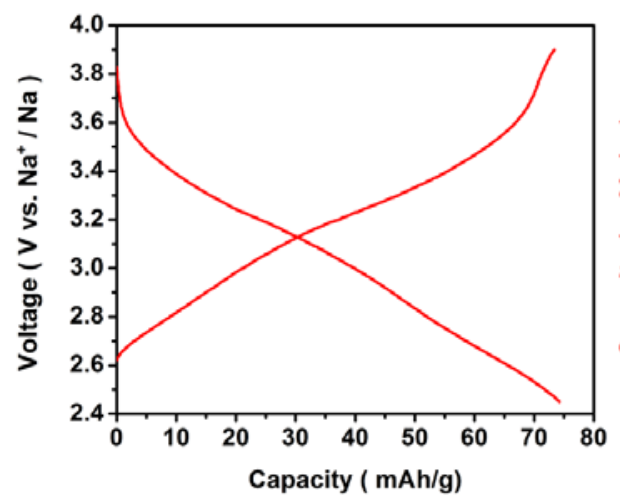

b

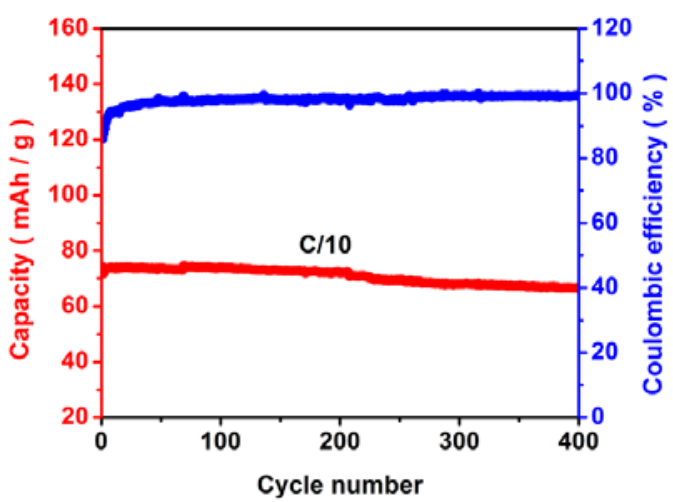

Figure 3 | Sodium storage performance of $\mathrm{Na}_{0.66}\left[\mathrm{Mn}_{0.66} \mathrm{Ti}_{0.34}\right] \mathrm{O}_{2}$ electrodes in nonaqueous solution. (a)The typical discharge/charge curves at a current rate of $0.1 \mathrm{C}$ in the voltage range of 1.5 and $3.9 \mathrm{~V}$ versus $\mathrm{Na}^{+} / \mathrm{Na}$. (b) Long-term cycling performance at a current rate of $0.1 \mathrm{C}$ for the $\mathrm{Na}_{0.66}\left[\mathrm{Mn}_{0.66} \mathrm{Ti}_{0.34}\right] \mathrm{O}_{2}$ electrode.
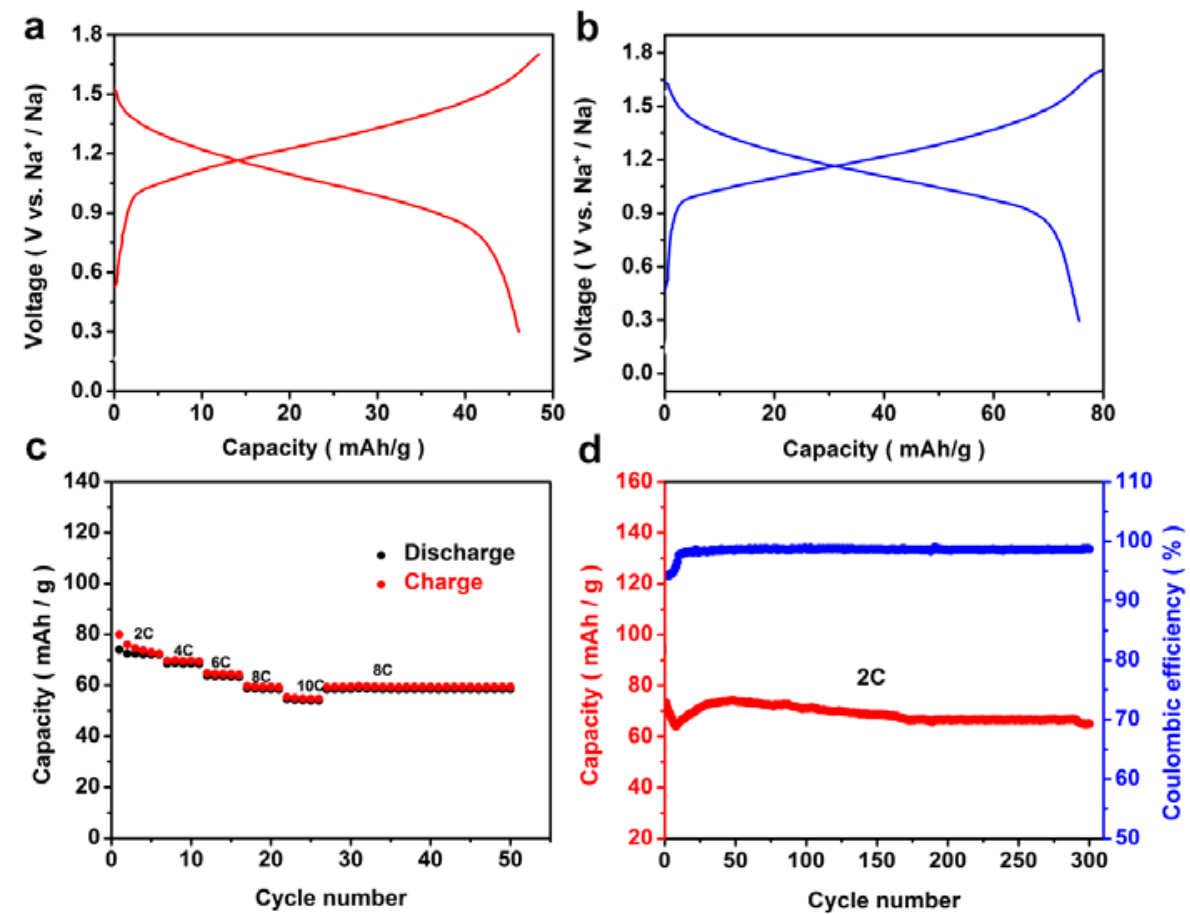

Figure 4 | Storage performance of full cells in aqueous electrolyte. The typical charge/discharge curves in the voltage range of 0.3 and $1.7 \mathrm{~V}$ for (a) $\mathrm{Na}_{0.44}\left[\mathrm{Mn}_{0.44} \mathrm{Ti}_{0.56}\right] \mathrm{O}_{2} \mid \mathrm{NaTi}_{2}\left(\mathrm{PO}_{4}\right)_{3} / \mathrm{C}$ and $\mathrm{Na}_{0.66}\left[\mathrm{Mn}_{0.66} \mathrm{Ti}_{0.34}\right] \mathrm{O}_{2} \mid \mathrm{NaTi}_{2}\left(\mathrm{PO}_{4}\right)_{3} / \mathrm{C}$ full cells $(\mathbf{b})$ at a current rate of 2C; (c) Rate performance of $\mathrm{Na}_{0.66}\left[\mathrm{Mn}_{0.66} \mathrm{Ti}_{0.34}\right] \mathrm{O}_{2} \mid \mathrm{NaTi}_{2}\left(\mathrm{PO}_{4}\right)_{3} / \mathrm{C}$ full cell cycled in the voltage range of $0.3-1.7 \mathrm{~V}$ at various current rates. (d) Cycling performance of $\mathrm{Na}_{0.66}\left[\mathrm{Mn}_{0.66} \mathrm{Ti}_{0.34}\right] \mathrm{O}_{2} \mid \mathrm{NaTi} 2(\mathrm{PO} 4) 3 / \mathrm{C}$ full cell at the current rate of 2C. 


\section{WILEY-VCH}
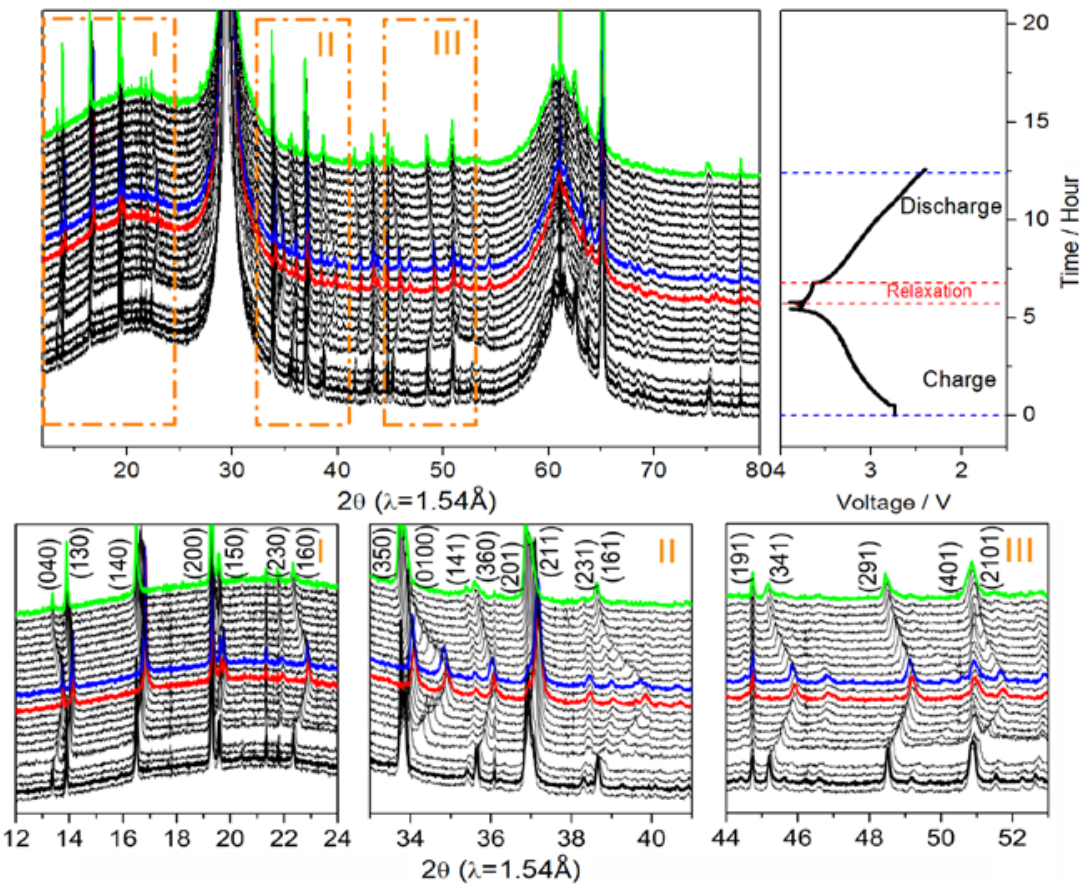

Figure 5 | Structure evolution upon Na extraction/insertion. In situ XRD patterns collected during the first discharge/charge of the $\mathrm{Na}_{0.66}\left[\mathrm{Mn}_{0.66} \mathrm{Ti}_{0.34}\right] \mathrm{O}_{2} \mid \mathrm{Na}$ half-cell under a current rate of $\mathrm{C} / 10$ at a voltage range between 1.5 and $3.9 \mathrm{~V}$. For comparison, the $2 \theta$ angle has been converted to values corresponding to the more common laboratory $\mathrm{Cu}$ Ka radiation $(\chi=1.54$ A).

Table 1: The electrochemical performance of various electrodes in aqueous electrolyte cells.

\begin{tabular}{|c|c|c|c|c|c|}
\hline Cathode & $\begin{array}{l}\text { Average } \\
\text { Voltage }\end{array}$ & Capacity (mAh/g) & $\begin{array}{l}\text { Current } \\
\text { rate }\end{array}$ & $\begin{array}{l}\text { Initial } \\
\text { efficiency }\end{array}$ & ref \\
\hline $\mathrm{Na}_{0.44} \mathrm{MnO}_{2}$ & $\begin{array}{l}1.1 \mathrm{~V} \\
\text { (vs. NTP) }\end{array}$ & 40 & $0.1 \mathrm{C}$ & $80 \%$ & 39 \\
\hline $\mathrm{NaMnO}_{2}$ & $\begin{array}{l}0.9 \mathrm{~V} \\
\text { (vs. NTP ) }\end{array}$ & 55 & $1 \mathrm{C}$ & $91.5 \%$ & 26 \\
\hline $\mathrm{Na}_{0.95} \mathrm{MnO}_{2}$ & $\begin{array}{l}1 \mathrm{~V} \\
\text { (vs. NTP) }\end{array}$ & 60 & $2 \mathrm{C}$ & $82 \%$ & 27 \\
\hline $\mathrm{Na}_{2} \mathrm{NiFe}(\mathrm{CN})_{6}$ & $\begin{array}{l}1.27 \mathrm{~V} \\
\text { (vs. NTP ) }\end{array}$ & 65 & $1 \mathrm{C}$ & $88 \%$ & 22 \\
\hline $\mathrm{Na}_{2} \mathrm{CuFe}(\mathrm{CN})_{6}$ & $\begin{array}{l}1.4 \mathrm{~V} \\
\text { (vs. NTP ) }\end{array}$ & 59 & $1 \mathrm{C}$ & $83 \%$ & 19,23 \\
\hline $\mathrm{NaVPO}_{4} \mathrm{~F}$ & $\begin{array}{l}1.15 \mathrm{~V} \\
\text { (vs. NTP ) }\end{array}$ & 54 & $1 \mathrm{C}$ & $75 \%$ & 25 \\
\hline $\begin{array}{l}\mathrm{Na}_{3} \mathbf{V}_{2} \mathbf{O}_{2 \times}\left(\mathrm{PO}_{4}\right)_{2} \mathbf{F}_{3-2 \mathrm{x}} \\
/ \mathrm{MWCNT}\end{array}$ & $\begin{array}{l}1.47 \mathrm{~V} \\
\text { (vs. NTP) }\end{array}$ & 46 & $1 \mathrm{C}$ & $98 \%$ & 30 \\
\hline $\mathrm{Na}_{0.66}\left[\mathrm{Mn}_{0.66} \mathrm{Ti}_{0.34}\right] \mathrm{O}_{2}$ & $\begin{array}{l}1.2 \mathrm{~V} \\
\text { (vs. NTP) }\end{array}$ & 76 & 2C & $88 \%$ & $\begin{array}{l}\text { This } \\
\text { work }\end{array}$ \\
\hline
\end{tabular}




\section{WILEY-VCH}

\section{The table of contents:}

Tunnel-type $\mathrm{Na}_{0.66}\left[\mathrm{Mn}_{0.66} \mathrm{Ti}_{0.34}\right] \mathrm{O}_{2}$ was successfully designed and synthesized as a positive electrode material for aqueous sodium-ion batteries. It shows a high reversible capacity of ca. $76 \mathrm{mAh} \mathrm{g}^{-1}$ at a current rate of $2 \mathrm{C}$ with an average voltage of $1.2 \mathrm{~V}$. The aqueous full-cell demonstrates excellent cycle performance with very small capacity decay after 300 cycles.

Keywords: Aqueous sodium ion battery, energy storage, positive electrode, tunnel-type structure

Yuesheng Wang ${ }^{1}$, Linqin $\mathrm{Mu}^{1}$, Jue $\mathrm{Liu}^{2}$, Zhenzhong Yang ${ }^{1}$, Xiqian $\mathrm{Yu}^{* 2}$, Lin $\mathrm{Gu}^{* 1}$, YongSheng $\mathrm{Hu}^{*}{ }^{1}$, Hong $\mathrm{Li}^{1}$, Xiao-Qing Yang ${ }^{2}$, Liquan Chen $^{1}$, Xuejie Huang ${ }^{1}$

Title: A novel high capacity positive electrode material with tunnel-type structure for aqueous sodium-ion batteries

\section{ToC figure:}

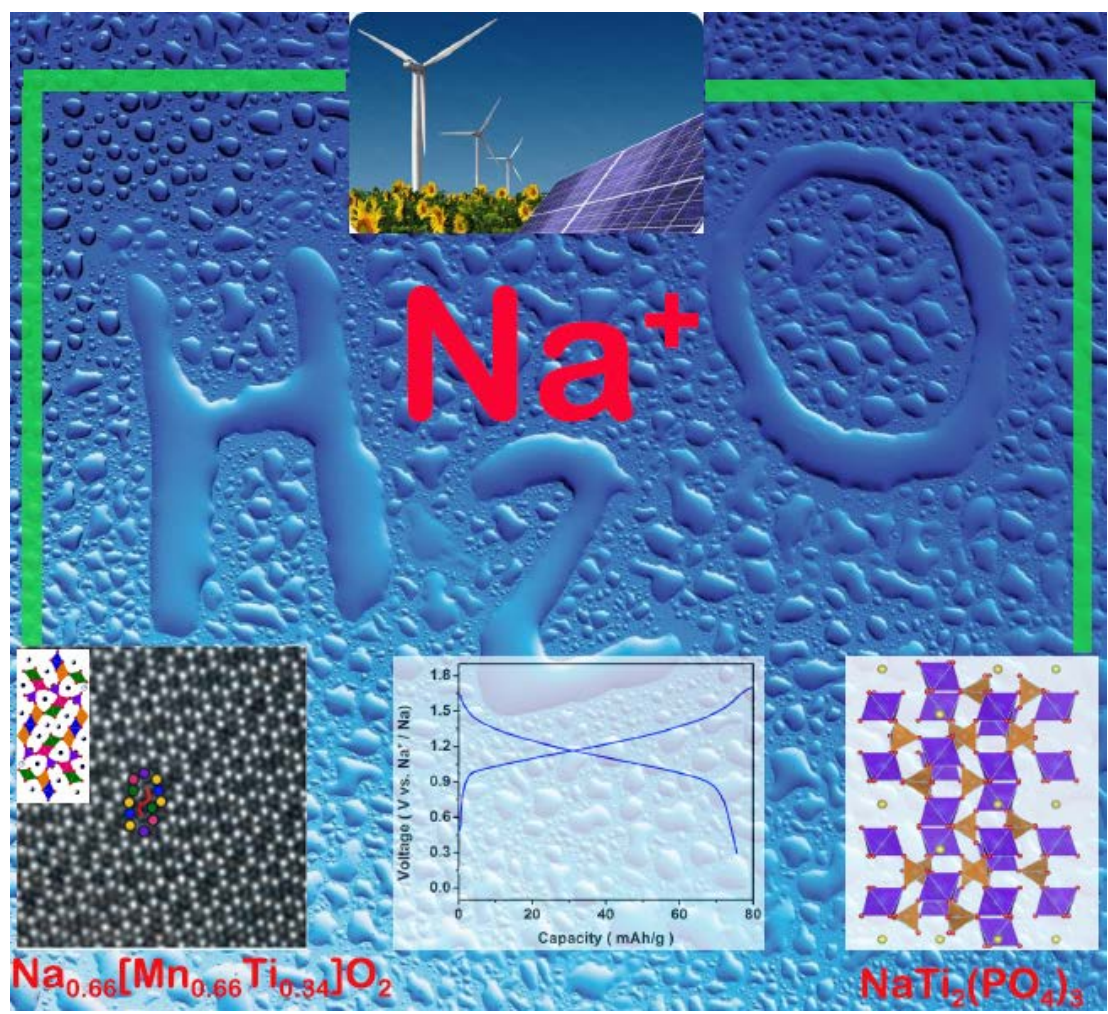

